\title{
FREITAS FILHO, Armando. Raro mar. São Paulo: Companhia das Letras, 2006.
}

\author{
Mário Alex Rosa \\ Universidade de São Paulo/UNI-BH
}

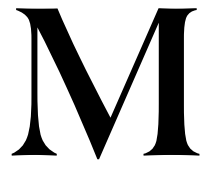

uitos poetas, como se sabe, deixaram registrados o seu olhar sobre a cidade de origem ou a que adotaram. O tema é bem antigo e, para não nos prolongarmos, fiquemos com os "Quadros parisienses" em As Flores do mal. Neles Baudelaire observou a capital francesa do século XIX como um flâneur. No Brasil, século $\mathrm{XX}$, Drummond escreveu tanto sobre Minas como também sobre o Rio de Janeiro, cidade que adotou. João Cabral, por sua vez, homenageou Pernambuco e Sevilha. Bem antes, Mário de Andrade, em 1922, publicou Paulicéia Desvairada, livro quase todo dedicado a São Paulo.

Em Raro Mar (2006), o poeta contemporâneo Armando Freitas Filho também percorre sua cidade, o Rio de Janeiro, travando com ela uma relação de amor e espanto. O contraste entre a beleza natural e a violência que assalta a cidade maravilbosa sugere a dialética como única possi-bilidade de observar esse lugar, pois, ao mesmo tempo em que o poeta é tomado pela beleza, essa lhe é roubada por um bloco de cimento armado que, aos poucos, diminui o horizonte e empareda a palavra, o poeta e os moradores, porque "A morte se transmite em código por celular rascante, funkeado".

Consciente dessa situação limite, já em Números anônimos (2004), livro excepcional, Armando Freitas não deixou de registrar magistralmente os acontecimentos transcorridos no Rio à época: "Rock, samba, funk cabeludo/ ou uma trilha para a guerra:/ escopetas, de sol a sol sempre/ no último furo, fuzilando", ou nestes versos de um tom áspero: "A cidade atravessa $\mathrm{O}$ dia/ engatilhada. /Anônimo, mata ao acaso/ e escapa, acossado/ atirando 
para o alto/ no alvo do sol certeiro".

O novo livro Raro Mar, guardadas as diferenças, lembra-nos Números anônimos. O retrato da cidade parece não ter mudado muito. No entanto, o olhar agora, embora ainda apaixo-nado, apresenta-se mais sentencioso como mostra o poema "Rio de Novo": "A cidade me rende mil montanhas/ o mar, que de tão onipresente/ não é mais visto nem a maresia/ sentida./ O céu passa abreviado/ o coração pára sob o sol obrigatório/ que continua batendo até o suicídio/ de cada dia,/ de todas as cores, na noite/ onde morrem convictas estrelas traçantes/ no palco armado para a lua./ A cidade me rende e imprensa - entre / paisagem e tráfico - à mercê da carne". É inevitável voltarmos nossa atenção para a força do poema e particularmente para a construção dos dois últimos versos onde os travessões reforçam a idéia de emparedamento entre o belo e a brutalidade do lugar, cujo nome encontra-se ironicamente no título do poema, ou seja, o novo já é velho e a carne, leia-se vida, fica à mercê de tudo. O diálogo dissonante entre beleza e violência continua em "Geral", "Firmamento", "Litoral" e "Morro", poemas que dão a dimensão de um poeta que caminha aberto a tempestades, observando os contrastes de sua cidade.
Ao lermos Armando Freitas, temos a sensação de que seus poemas são um amálgama dos sentidos, sobretudo o da visão, o da audição e o do tato (se pensarmos no erotismo, um dos núcleos sempre presentes). Os sentidos aguçados do poeta parecem não querer perder detalhe algum. Tudo é captado e bem estruturado em cada verso. O poeta deseja aliterar tudo; evidentemente sem nenhum artifício frio e calculado, como percebemos no ritmo pulsante do belo poema "Litoral", onde tudo pode acontecer em frações de minutos diante de um sinal de trânsito.

É importante frisarmos que a poesia de Armando Freitas está longe de uma proposta engajada ou de uma poesia social presa ao mundo real. Ao contrário, ela mimetiza de forma crítica o mundo no qual o poeta vive. A urgência de não deixar escapar nada, de se colocar no risco entre poesia e vida, mostra-nos a inquietude de um poeta que deixa transparecer as impurezas. A ferida parece estar sempre aberta. Talvez seja por isso que a crítica nunca hesitou em chamá-la de uma poética visceral. E não há outra maneira senão deixar tudo exposto, porque esse é um modo de estar no mundo sem aparar as arestas.

Se, por um lado, Raro Marconflitua com paisagens, por outro, Armando Freitas continua dialogando com 
dois poetas caros a sua formação: Drummond e Cabral. Essa troca é marcada por tensões de adesão e negação. Tudo se impõe como se lêlos fosse uma maneira de se libertar deles. Entretanto, ao que nos parece, quanto mais Armando Freitas escreve mais ele acentua a admiração a Drummond e a negação, ainda que muito bem formalizada, da construção cabralina. Nota-se ironicamente que no título "Outra receita", o poeta propõe uma exposição mais misturada entre, digamos, a pedra e o feijão, o bruto e o lapidado que fazem parte da anti-receita freitasiana. Em Drummond, a tensão é ainda maior, pois o eu retorcido do poeta mineiro parece retorcer o poeta carioca, e o que se vê é uma inflexão de um poetaleitor que não oscila em afirmar que a poesia de Carlos Drummond nos atravessa para sempre.

Afora esses diálogos, há poemas que nos remetem às artes plásticas, como "Ar e terra", uma bela homenagem ao escultor Amílcar de Castro. Lendo-os, reencontramos a própria poética de Armando. Dizer do outro é dizer também de si mesmo. É como uma metalinguagem, um modo de falar da construção do próprio poema. E, por fim, há toda uma seqüência de poemas nomeados por números, já iniciados em Numeral Nominal, reunidos em Máquina de Escrever (2003). A sensação é que essa nume- ração - toda datada - é um desafio para o próprio poeta, pois, se os números são infinitos, até quando será capaz de numerar? Até onde pode ir a criação? Ela tem limites? Não temos respostas, ou melhor, ficaremos aguardando os próximos livros do poeta.

A rigor, essa obstinação não tem o caráter de uma máquina de escrever que reproduz em série. $\mathrm{Na}$ verdade, o que caracteriza essa busca, é uma mistura de um poeta verdadeiramente apaixonado pela palavra, pelo fazer, por querer estar sempre desafiando a si mesmo e a linguagem. Enfim, um poeta que procura saber até onde a sua linguagem pode alcançar. É uma verdadeira batalha do dizer, do nomear e numerar, uma obsessão, pois "A noite desafia o dia/ que cada dia é menos um" ("41"). Assim, Armando se coloca diante do risco da criação, porque o amálgama entre vida e poesia parece se alimentar um do outro. Desse modo, a falta de um pode resultar no que diz o verso do poema " 44 ": "Parar de escrever pode ser morrer". Aqui a tensão do limite é marcada pelo tempo de vida que resta: cada dizer é um escrever a menos, é menos um poema, é não dissociar vida e morte. Um exemplo é o belíssimo poema "62", onde tempo, memória, passado e presente encontram-se no diálogo com a imagem paterna. 
É importante ressaltarmos que a numeração crescente não é apenas uma série ou um jogo de efeitos criativos. O sentido não está na numeração em si, mas no que o poeta se propôs a fazer, ou seja, numerar até quando a vida e a poesia permitirem. O que nos chama a atenção nessa numeração é a relação que o poeta trava entre passado e presente, entre o aqui, o agora, e o que já ficou para trás. A fórmula seria mais ou menos assim: aproximar-se do fim é também distanciar-se dele, recordar é guardar de novo no coração. O exercício de relembrar é, na poesia de Armando Freitas, um modo de encarar a "indesejada da gente", seja qual for. No caso de Armando é o corpo, os amigos, o Rio de Janeiro, a poesia, a morte e, enfim, a vida. 